\title{
有機超薄膜の非占有準位・分光イメージングと ナノスケール構造観察
}

\section{Unoccupied States Measurements, Spatial Mapping, and Nanoscale Structures of Organic Ultrathin Films}

\author{
山田 剛司
}

Takashi Yamada

\begin{abstract}
In this accounts, we summarize recent progress in experimental approaches to the investigation of the unoccupied electronic structures of organic ultrathin films, based on a combination of spectroscopic and microscopic techniques On the occupied valence bands of the films, it has been extensively studied for a variety of organic molecules. However, systematic investigations of unoccupied electronic states still have been challenging because experimental techniques are limited. In this context, we have clarified the correlation between geometric and electronic structure using a combination of two-photon photoemission (2PPE) spectroscopy and scanning tunneling microscopy (STM). By using 2PPE, one can measure unoccupied states as well as occupied states in the vicinity of the Fermi level. Beyond the diffraction limit of light, STM can be a powerful means of mapping unoccupied electronic structures, not limited to the imaging of geometrical structures. Depending on the molecular density and substrate temperature, organic ultrathin films of polycyclic aromatic hydrocarbons on graphite substrates show a variety of structures, as demonstrated by microscopic observations on the nanoscale. It is apparent that the geometrical structures, especially molecular orientations as stressed throughout this accounts, have a strong impact on both occupied and unoccupied electronic structures. These findings, with a spectroscopic and microscopic understanding at the level of molecule, will provide fundamental insights into desirable electronic properties at organic/substrate interfaces.
\end{abstract}

Keywords: organic ultrathin films, unoccupied electronic states, scanning tunneling microscopy (STM), two-photon photoemission (2PPE) spectroscopy

\section{1. はじめに}

有機分子／基板界面において，単分子層程度の膜厚を持 つ有機超薄膜の表面電子状態を理解することは分子科学と しての興味にとどまらず，有機発光素子や有機薄膜太陽電 池など，各種有機デバイスの動作原理を理解する上でも重 要な鍵となりうる ${ }^{1-4}$ 。これは, 界面電子状態の描像を得る ことが, 電極からの電荷注入や有機層における励起子生 成・電荷分離・電荷輸送といった素過程への理解に直結す るためである。一般的に，分子／基板界面においては Figure 1 に例示するように, 各種の分子間相互作用や分子一 基板間相互作用が協奏する場となり，気相・液相・固相 （結晶）とまったく異なった電子状態が形成される。特に, 単分子層程度の膜厚を持つ超薄膜の電子状態については, 分子集合体の構造や分子配向と密接な関係がある。このた め，薄膜の構造を規定したうえで両者の相関を議論するこ とが重要となる。

現実の系でどのような構造・電子状態を取るかは, 分子 間相互作用や分子基板間相互作用のバランスによって決ま るところが大きい。固体表面上における分子集合体のサイ ズは，典型的にはナノメートルからマイクロメートルに及
Molecules on substrate

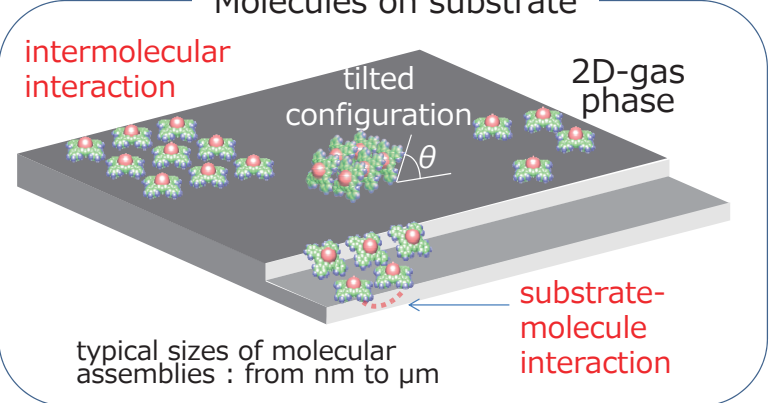

Figure 1. Schematic illustration of different types of molecular aggregates on a substrate, assembled by the delicate balance between intermolecular and substrate-molecule interactions. Typical sizes of aggregates at the organic/substrate interface range from the nano to micrometer scale.

ぶ広範なスケールとなる。また, Figure 1 で例示した相互 作用の大きさは，有機分子の場合には概ね $100 \mathrm{meV}$ 以下程 度であり ${ }^{1-4}$, 金属・無機半導体と比べても小さな值をとる。 このため，分子集合体を見分けることができる十分に高い 空間分解能と，相互作用を見分けることができるエネル ギー分解能とを両立させて構造・電子状態に関する知見を 得ることが求められている。例えば, 鉛フタロシアニン超 
薄膜を例に取ると, 筆者所属の研究グループでは, 固体表 面上で 2 次元ガス状に分布した相 ${ }^{5}$, 特定の分子配向を保っ て吸着した準安定相 ${ }^{6}$, 表面原子に対して特定の周期性で 配列した安定構造を持つ相 ${ }^{7-9}$ について, 分子レベルでそ の構造を規定したうえで電子状態を同時に計測し，両者の 相関を議論してきた。上記の系では同一種類の分子／基板 界面の組み合わせであっても，配向や吸着構造が異なるた けで電子状態が大幅に変化することが判明している。

これまでの表面科学の歴史を振り返ってみると, 金属結 合や共有結合によって構成された, 比較的強固な金属・半 導体表面を評価するのに適した観測手法の開発には長足の 進歩があった ${ }^{10,11}$ 。一方, 本研究で対象とする有機分子. 有機半導体分子は上記に比べて弱い相互作用で凝集する。 このため, 目的に適う十分に高い分解能をもって, 非破壊 で電子状態計測や構造観察を行うことが求められている。 界面に形成される電子状態のうち, 占有準位（価電子帯） については紫外光電子分光法（Ultraviolet Photoemission Spectroscopy, UPS, Figure 2（a）によって精力的かつ系統 的な研究が行われている ${ }^{1-4,10-15}$ 。これは真空紫外光や放射 光を光源として用い, 占有準位にある電子を 1 光子過程 (one-photon photoemission, 1PPE) で励起し, 真空中に放出 された電子をエネルギー分析することで占有準位を評価す る手法である。一方, 電子の詰まっていない非占有準位 (伝導帯) に着目すると, 実験的に計測可能な分光手法が限 定されていることもあり，その測定例はかなり限られてい る 16 。

光電子分光の逆過程を利用する逆光電子分光法 (Inverse Photo Emission Spectroscopy, IPES）は，非占有準位を計測 することができる有効な手法の一つとして挙げることがで きるが，プローブとして用いる電子線によって有機薄膜が 破壊されやすいことや，エネルギー分解能が十分でない (>300 meV) といった課題も残されていた ${ }^{10-12}$ 。なお, 吉 田ら (千葉大学) によって上述の点を改善した手法が近年
報告され，種々の有機薄膜に適用され始めている ${ }^{17,18}$ 。ま た，非占有準位のエネルギー位置を求める方法として，吸 収分光の結果に基づき, 光学ギャップの值から物質の非占 有準位が求められることもある。しかしながら, 光吸収に よって求められる励起子準位は, 正孔の影響がない電子が 入る非占有準位とは異なるため, 両者の差異を丁寧に議論 することが必要である ${ }^{16}$ 。本稿では，筆者がこれまでに取 り組んできた, 有機超薄膜の表面構造観察や非占有準位計 測を中心とし, 分光イメージングも含めた最近の研究の進 展状況について紹介したい。

\section{2PPE/STM 局所分光による非占有準位の計測}

上述の背景を踏まえ, 筆者は 2 光子光電子分光法（TwoPhoton Photoemission, 2PPE, Figure 2 (b)）と走査トンネル 顕微鏡法（Scanning Tunneling Microscopy, STM）, STM を 用いた局所分光法を展開し，有機分子超薄膜の構造と非占 有電子状態の相関を分子レベルで理解することに取り組ん できた。2PPE ${ }^{19-23}$ は光源に波長可変フェムト秒・チタンサ ファイヤレーザー（波長 780-920 nm，パルス幅 $100 \mathrm{fs}$ ，繰 り返し周波数 $80 \mathrm{MHz}$ ) の高調波を用いる光電子分光法で ある。本稿で紹介する実験では，光子エネルギーを仕事関 数程度 $(h v=4.03-4.77 \mathrm{eV})$ に設定して 1 光子励起過程を 抑え，かつレーザーによる薄膜の損傷が起こらないよう出 力を調整して $(0.13 \mathrm{~nJ} / \mathrm{pluse})$ 測定している。

2PPEの励起過程として, Figure 3 (a) に示すように, (1) 占有準位 $E_{\mathrm{i}}(<0)$ からの 2 光子同時吸収が起こる過程と, (2) 中間状態として非占有準位 $E_{\mathrm{m}}(>0)$ を経由した後に光電 子放出が起こる 2 段階励起がある。（2）の過程では，一つ 目の光子 (ポンプ光)によって占有準位にあった電子が非 占有準位に励起され，二つ目の光子（プローブ光）によっ て真空準位 $\left(E_{\mathrm{vac}}\right)$ 上に放出された光電子の運動エネルギー $\left(E_{\text {kin }}\right)$ を電子分光器で計測する。この際, Figure 3 (a) の 模式図に示すように，励起波長を変えながら $2 \mathrm{PPE}$ 測定を
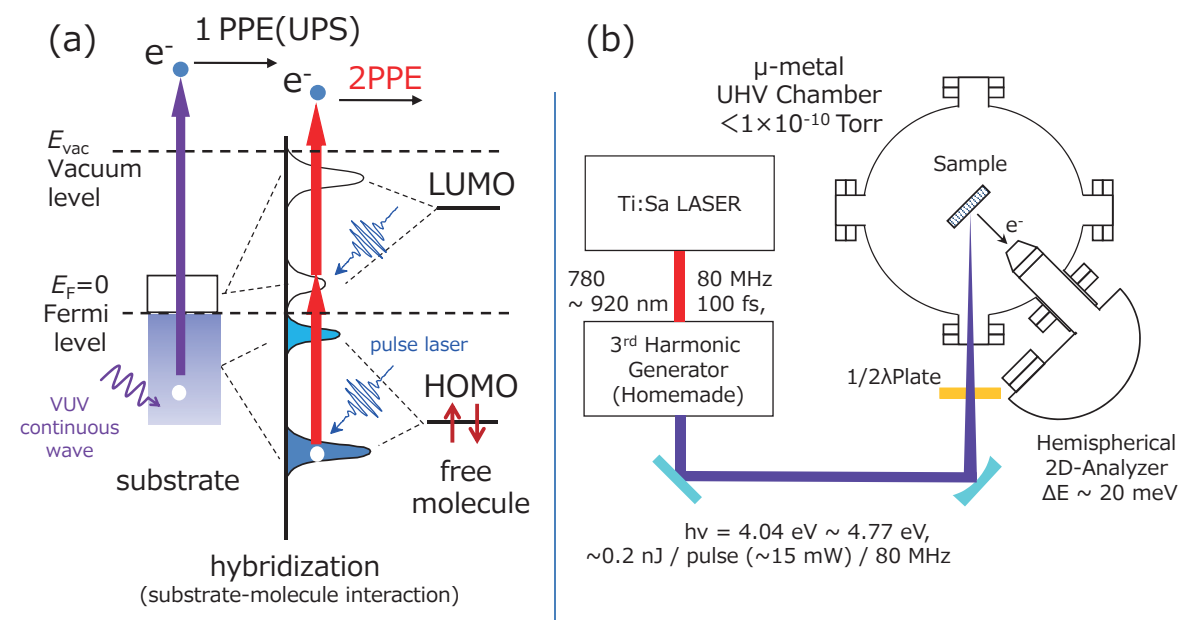

Figure 2. Schematic illustration of (a) 1PPE (UPS, left) and 2PPE (right) processes. (b) Schematic illustration of the experimental setup for 2PPE. 
(a) 2PPE processes

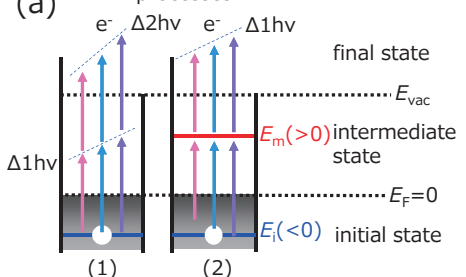

(b)

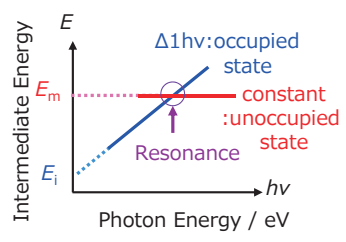

(1) two-photon absorption

(2) two-step process

Figure 3. (a) Basic concepts of the 2PPE excitation processes: (1) a direct two-photon absorption from an occupied state. (2) a two-step process via an intermediate state, in which an initial first photon (a pump photon) excites an electron from an occupied state $\left(E_{\mathrm{i}}(<0)\right)$ to an intermediate unoccupied state $\left(E_{\mathrm{m}}(>0)\right)$. The second photon (probe photon) lifts the electron above the vacuum level, with kinetic energy of electron of $E_{\text {kin }}$. (b) When 2PPE spectra acquired with different photon energies are on an intermediate energy scale defined as $E_{\mathrm{kin}}-h v$, the photoemission peak from the intermediate state aligns at a fixed energy value of $E_{\mathrm{m}}$. The peak generated by an occupied initial state shifts with a slope of one as the photon energy is increased, such that unoccupied and occupied states can be distinguished.

行い, 観測された各ピークを $\left(E_{\mathrm{kin}}-h v\right)$ で定義される中 間状態でプロットし, Figure 3 (b) のように表示すること で，占有・非占有準位を経由した光電子を区別することが できる。また, 光子エネルギーが占有・非占有準位間のエ ネルギー差に近接してくると, 共鳴励起が起こり, 光電子 放出強度が増大する。

なお，本稿では詳細に触れないが，光源がパルスレー ザー光であることを利用し, 回折限界付近までビーム径を 絞って行う顕微 $2 \mathrm{PPE}^{24-26}$ や， ポンプ・プローブ分光法に よる時間分解 $2 \mathrm{PPE}^{22,23,27,28}$ へ展開することも可能である。

STM は金属探針を試料近傍に近接させ, トンネル電流を 一定にしつつ（定電流モード）, 探針を 2 次元走査させなが ら高さ情報を記録することにより，ナノスケールにおいて 表面構造観察を行う手法である 29 。本研究ではSTM で像取 得を行うと同時に, 表面上の任意の点において局所分光を 行い, 電子状態のマッピングを行っている。これにより, 有機超薄膜における非占有準位をナノスケールで計測・可 視化（分光イメージング）させることが可能となる。分子 レベルで得られた膜の構造と, 電子状態とを 1 対 1 で対応 付けて理解することによって, 表面電子状態の描像を分子 レベルで得ることが可能となる。

実験はすべて超高真空中 $\left(1 \times 10^{-10}\right.$ Torr 程度 $)$ で行った。 計測対象とする試料については, 超高真空中に保持した清 浄基板に有機分子を逐次蒸着させることで超薄膜を作製し た。また, 使用する有機分子については, 製薬会社から購 入後, 高真空中 $\left(10^{-6}\right.$ Torr 程度) で複数回の昇華精製を行 い，不純物を除去した後に使用している。基板については， 高配向性熱分解グラファイト (Highly Oriented Pyrolytic Graphite, HOPG）もしくは単結晶グラファイト（天然産出） を使用し，いずれも大気中にて䢃開後，超高真空中におい て加熱アニール（約 $670 \mathrm{~K}, 60$ 時間程度）を行うことに
よって清浄表面を得ている。

\section{3. ナフタレン超薄膜における構造と電子状態との相 関解明}

本節では, 比較的単純な分子構造を持つ芳香族炭化水素 であるナフタレン $\left(\mathrm{C}_{10} \mathrm{H}_{8}\right)$ を取り上げ，2PPE， STM，低 速電子線回折（Low-Energy Electron Diffraction, LEED）を 併用し, 超薄膜の構造と電子状態の比較を行った例を紹介 する ${ }^{30-32}$ 。LEED は単色化した低速電子線（数 $10 \mathrm{eV〜200}$ $\mathrm{eV}$ 程度）を試料表面に当て, 得られた回折像から表面構造 の周期性を計測する手法である ${ }^{10,11}$ 。本研究では回折像を Micro Channel Plate（MCP）を用いて増幅検出している。通 常の LEED 測定に比べて試料への照射電流を $1 / 10$ 以下に抑 えられる利点があるが，半球型スクリーンに投影される LEED 像が平板状の MCP で増幅されるため, 観測される LEED 像の歪みが通常より大きくなってしまう点が問題と されている ${ }^{33}$ 。本研究では, 構造が良く規定された $\mathrm{Si}(111)$ $(7 \times 7)$ 表面を用い, 像の歪みや電源のエネルギーオフセッ トに由来する入射電子エネルギーのずれをあらかじめ校正 したうえで有機超薄膜に適用し, 定量的な構造解析を可能 にしている33。

ナフタレン分子自体は単純な構造を持ち, 固体では単一 の結晶構造を持つ 34 。LEED を使用して構造解析を行った ところ，グラファイト基板上では，基板温度や膜厚により 少なくとも 6 種類の超構造が存在することが明らかになっ た ${ }^{32}$ 。 Figure 4 に基板温度・分子吸着量をパラメータとし た相図を示す。このような多彩な構造を取る理由として, 基板温度の高／低によって分子間相互作用がそれぞれ斥 力 $/$ 引として働く領域が存在することに加え, 表面分子 密度の増加に伴って, 分子間力が顕著に働く領域が入り組 むためである ${ }^{32}$ 。実際に多層領域に現れる REC 相 (rectangular 相) では, ナフタレン単結晶の (001) 面 ${ }^{34}$ と似通った, 長方形の単位格子を取ることがわかった。Figure 4 に示し た相のうち, 単一相が出現しやすく構造が安定である, $\mathrm{COM}$ 相 $\left((2 \sqrt{3} \times 2 \sqrt{3}) R 30^{\circ}\right.$ 構造, 以後 $2 \sqrt{3}$ 構造と表記 $)$ と REC 相を中心に, UPS/2PPEをもちいた占有・非占有電子 状態計測とSTMによる構造観察・局所分光を行った。

なお，COM 相は commensurate 相（整合相）の略称であ り, 実空間において吸着分子が作る超構造の周期性は基板 の単位格子ベクトルを整数倍した線形結合で記述できる。 一般的に，金属・無機半導体表面上では吸着物質と基板間 の相互作用が強いため，このような整合相の観察例が多く 報告されている 10,11。また, Figure 4 の相図中, HOC, PoL はそれぞれ higher order commensurate, point on lineの略称で ある。両相についても LEED では明瞭な回折像が確認され ており ${ }^{32}$, 基板に対する超構造の周期性が存在するため整 合相の範疇に入る。COM 相と異なる点は, 吸着分子が作る 超構造の周期性が, 基板の単位格子ベクトルに対して非整 
数倍の線形結合で記述される点にあり ${ }^{35}$, このような相で は分子間にはたらく引力相互作用が優位に作用しているこ とが予想される。近年, サイズの大きな有機分子を吸着さ せた系において，かなり長周期の構造を持つ相の存在が報 告され始めており，「整合」という言葉の範囲で記述される 構造をより正確に分類する必要性が生じている ${ }^{35}$ 。

Figure 4（a）の相図において, 矢印に沿った方向（基板 温度 $150 \mathrm{~K}$ 程度）にてナフタレン吸着を行うと, 膜厚増加 とともに COM 相から（HOC 相との一部共存を経て）最終 的に REC 相への構造変化が観測される。Figure 5 (b) に $\mathrm{COM}$ 相の STM 像を示す。グラファイト基板の周期性を強 く反映した $2 \sqrt{3}$ 構造が出現しており，分子面をグラファイ 卜表面にほぼ平行にして吸着する，「寝た配置」をとること がわかった。一方で, Figure 5（b）のSTM 像を高空間分解 能で取得し，その高さプロファイルを解析したところ，分 子長軸方向に沿ってわずかに傾いた形で吸着していること が判明した ${ }^{30}$ 。Wella らによって行われた吸着エネルギー計 算 36 によると, 分子同士が近接して $2 \sqrt{3}$ 構造が形成され るようになると，パウリ反発による斥力項が無視できなく なり，分子長軸方向にわずかに傾いた配置が最安定である ことが示されている。また, 実験で得られた STM 像はシ ミュレーションによってもよく再現されることが判明して いる 36 。

REC 相の STM 像を Figure 5（c）に示す。○印で囲んだ
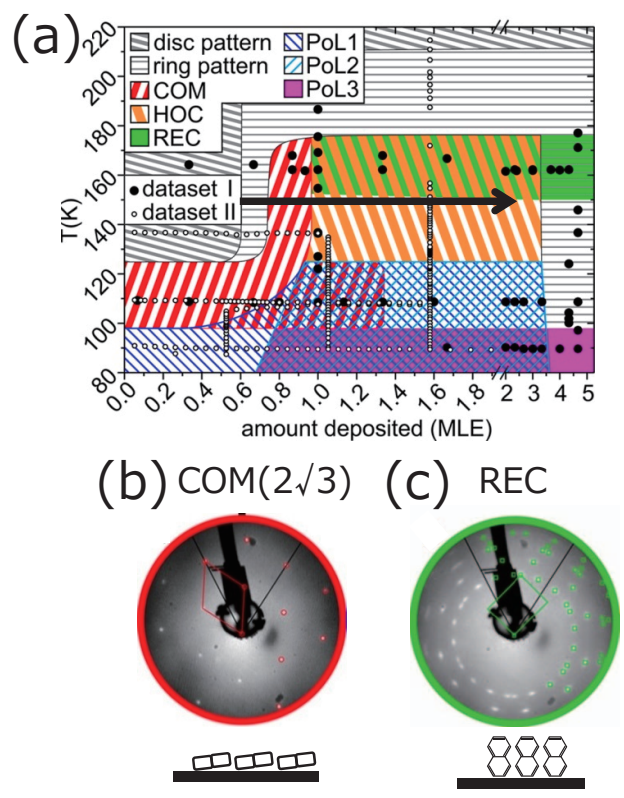

Figure 4. (a) Phase diagram of naphthalene on graphite. Depending on the coverage and substrate temperature, a total of 6 ordered-phases are confirmed for this system. Along the black allow $(\sim 150 \mathrm{~K})$ in the phase diagram, coverage dependent $2 \mathrm{PPE}$ experiments were conducted as introduced in Figure 6. LEED patterns of naphthalene on graphite, (b) a commensurate $(\mathrm{COM})$ phase with a $(2 \sqrt{3} \times 2 \sqrt{3}) R 30^{\circ}$ periodicity and (c) a densely packed rectangular (REC) phase. Primary electron energies were (b) $50.9 \mathrm{eV}$ and (c) $76.3 \mathrm{eV}$, respectively. HOC, and PoL in (a) means higher order commensurate phase and point on line phase, respectively. Reproduced from ref. (32) with permission (Copyright 2016 American Chemical Society).
輝点一つが欠陥として観測される場合があることから ${ }^{32}$, 輝点一つがナフタレン一分子に対応することがわかる。ナ フタレン一分子の占有面積は最低でも $0.33 \mathrm{~nm}^{2} 37$ と見積も られ，分子が寝た配置を取ったままで REC 相の単位格子 $\left(0.41 \mathrm{~nm}^{2}\right)$ に2 分子を収容することは不可能となる。した がって REC 相ではナフタレンの分子面を基板に対して立て た配向で吸着していることがわかる ${ }^{38}$ 。

各相における構造と分子配向が判明したところで, Figure 4 (a) の相図中, 矢印に沿った方向（基板温度 $150 \mathrm{~K}$ 程度） にてナフタレンを吸着させて取得したUPS/2PPE スペクト ルを Figure 6 に示す。ここでは, 最高占有準位（Highest Occupied Molecular Orbital, HOMO), 最低非占有準位（Low-

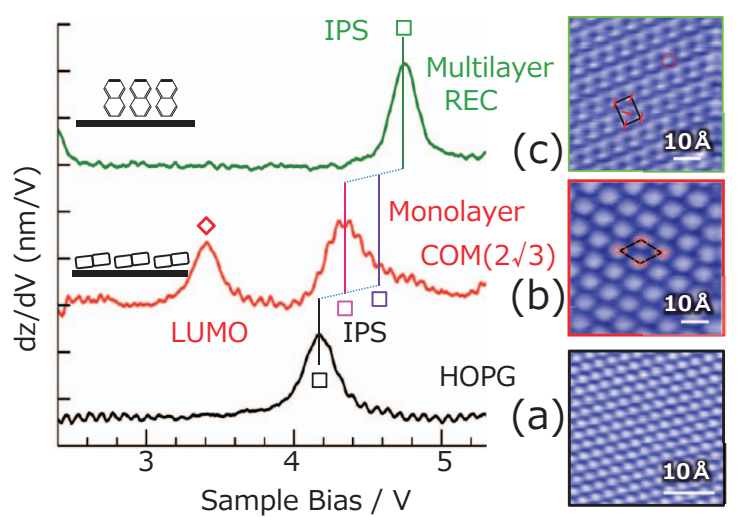

Figure 5. The $\mathrm{d} z / \mathrm{d} V$ spectra along with STM images for (a) a HOPG clean surface, (b) a COM phase and (c) a REC phase multilayer film. The tunneling current was set to $20 \mathrm{pA}$ for all measurements. The scale bars in the STM images indicate $10 \AA$. Reproduced from ref. (31) with permission (Copyright 2014 American Chemical Society).

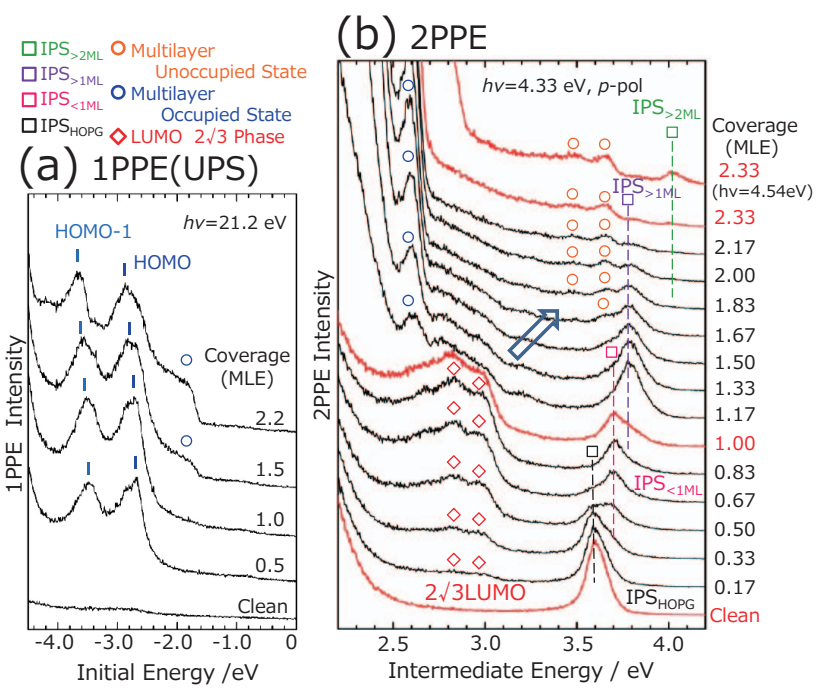

Figure 6. (a) Coverage-dependent 1PPE spectra acquired at a photon energy of $21.2 \mathrm{eV}$ (UPS). At coverages above $1 \mathrm{ML}$, adsorption-induced occupied states (blue circles) are observed on the higher energy side of the HOMO peak. (b) Coverage-dependent 2PPE spectra acquired at a photon energy of $4.33 \mathrm{eV}$ (except for the topmost one, acquired at 4.54 $\mathrm{eV})$. Dotted lines with open squares indicate the energy positions of the IPS. Other spectroscopic features indicated by open circles and diamonds are adsorption-induced states of naphthalene. Coverages are given by monolayer equivalent (MLE) unit. Reproduced from ref. (31) with permission (Copyright 2014 American Chemical Society). 
(a)
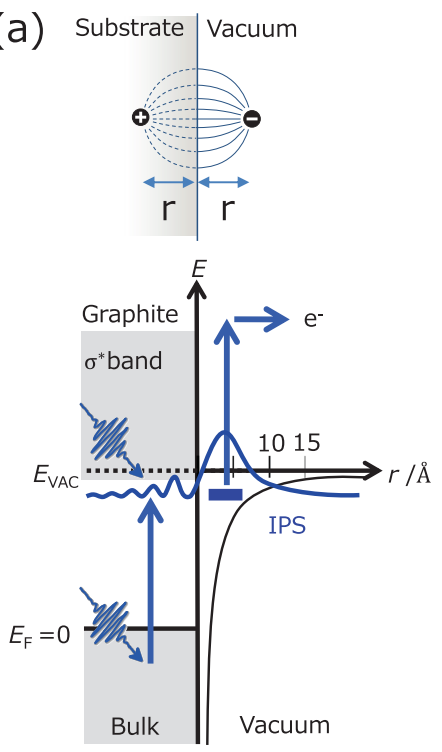

(b)

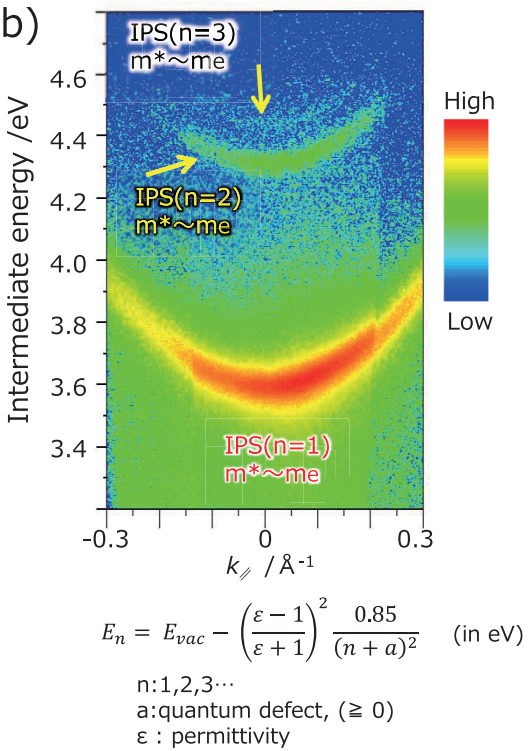

Figure 7. (a) Schematic model of image potential state (IPS). The IPS is a Rydberg-like series of image-potential states, supported by a potential well formed by the Coulombic image potential and the projected band gap of the substrate. (b) Angle-resolved 2PPE of IPS $(\mathrm{n}=1,2,3)$ measured for single crystalline graphite. Nearly free-electron like momentum-energy dispersions are observed. These unoccupied surface electronic states are typically observed in the case of uniform ultrathin films acting as adsorbates as well as on clean substrates.

est Unoccupied Molecular Orbital, LUMO）や表面鏡像準位 (Image Potential State, IPS) が構造 (膜厚) に依存して変化 する様子を捉えることができた。基板に由来する表面鏡像 準位 $\left(\right.$ IPS $\left._{\mathrm{HOPG}}\right)$ は分子層が表面を覆うと消失するため ${ }^{23,39}$, これを利用して膜厚を見積もることができる。本系では吸 着量増加に伴う構造変化があるため, 膜厚を厳密に決定す

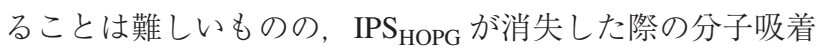
量を 1 MLE (monolayer equivalent) とし, 膜厚の定義とし て便宜上使用している。また, UPS (Figure 6 (a)) につい ては2PPE と同じ超高真空容器内で同時に測定を行った結 果をもとに，共通の吸着量単位を使用している。

表面鏡像準位（IPS）の由来に関し, 固体表面近傍に電子 が励起されると, 基板側に鏡像電荷が存在する場合と同様 の静電ポテンシャルを感じる（Figure 7 (a))。表面に投影 されたエネルギーバンドの一部に禁制帯が開いていると, バンドギャップと鏡像ポテンシャルによって支えられた束 縛状態が表面外側に形成され, 非占有状態の表面準位とし て IPES や 2PPE の観測にかかるようになる 12,39-42。IPS は 表面垂直方向には緩い束縛準位となるが, 表面平行方向に は自由電子的に振る舞う。Figure 7 (b) に単結晶グラファ イト清浄表面の角度分解 $2 \mathrm{PPE}$ の結果を示す。IPS に励起さ れた電子の有効質量を分散曲線の曲率から評価すると, 自 由電子の質量とほぼ等しい值をとることがわかった。均一 な分子薄膜が形成される場合には, 膜上においても IPS が 観測されるが 5-9,23-28, 角度分解 2PPE を行うことで分子由 来の非占有準位と区別を行うことができる ${ }^{31}$ 。 IPS は膜の モルフォロジーを鋭く反映し，そのエネルギー位置は膜の
誘電率や仕事関数によって変化することが知られている ${ }^{42}$ 。

Figure 6（b）における2PPE スペクトルでは, ナフタレ ン膜上のIPS ピークが吸着量に応じて観測されている。ナ フタレンはテラス構造を伴って層状成長をしていることが 予想され，広範囲で取得したSTM 像とも整合している ${ }^{30}$ 。 ここでは, 吸着量増加に伴って IPS が高エネルギー側へ徐々 にシフトする様子が見られた。この系では, 吸着量増加に 伴う仕事関数変化がほとんどないため, IPS ピークのエネ ルギー変化は主に膜の誘電率変化に由来する効果として説 明できる（Figure 7 (b) 中の式参照 ${ }^{42}$ )。Figure 6（b）にお いて IPS $<1 \mathrm{ML}$ ならびに IPS $>2 \mathrm{ML}$ については, それぞれ $\mathrm{COM}$ 相（2 $\sqrt{3}$ 構造）および REC 相の膜上の IPS に由来し ている。一方, 両者の中間領域で IPS $>1 \mathrm{ML}$ とラベル付けし たピークはかなり広い裾を持って観測され，1 MLE 前後で は分子密度 (誘電率) がわずかに異なった相が混在してい ることを反映している。実際に Figure 4 の相図においても, 対応する相図中の領域で, COM 相よりわずかに大きな分子 密度を持つ HOC 相が入り組んで存在している ${ }^{32}$ 。また, 顕 微分光を行わない, 典型的な $2 \mathrm{PPE}$ 測定時のレーザースポッ 卜径は $100 \mu \mathrm{m}$ 前後であり, 文献 ${ }^{30}$ の $150 \mathrm{~nm}^{2}$ 程度の STM 像で種々の膜厚によるドメインが観測されていることから 考えても, 1 MLE 付近の吸着量では, 似通った誘電率（分 子密度）をもつ複数の相が $2 \mathrm{PPE}$ のプローブ範囲内に混在 していると考えられる。

HOMO/LUMO ピークについては多層膜の形成に伴って, かなり大きなエネルギー変化が観測された。具体的に, Figure 6（a）の占有準位については，(REC 相が主となる） 
多層膜で HOMO の高エネルギー側に肩成分（青○印， -1.8 $\mathrm{eV}$ 付近）が出現し, Figure 6 (b) の 2PPEでも多層膜にお いてのみ, 相当する位置に占有準位由来のピークが出現し た (青O印)。LUMOについては $2 \sqrt{3}$ 構造に由来する LUMO

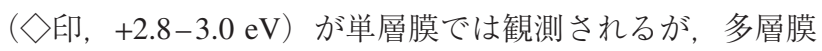
では同じ位置には観測されなくなり, HOMOの場合と同様 に本来の位置よりも高エネルギー側 $(+3.5-3.7 \mathrm{eV})$ にピー クシフトしている。なお, HOMO-LUMOのギャップの值 については, 単層膜・多層膜とも, グラファイト基板上の 吸着単分子で計算されたものと良い一致を見せており ${ }^{43}$, ここで見られた膜厚に依存するエネルギー変化は分子配向 の変化そのものに対応している。

他の分子吸着系においても, 膜厚や基板の種類を変える ことによって $0.5 \mathrm{eV}-1 \mathrm{eV}$ 程度に及ぶ占有準位のエネル ギー変化が観測されたという結果が報告されており $44-46$, 分子配向の変化が原因であるとされている。具体的には, 分子配向の変化によって分子基板界面で分子内に電荷分布 の偏りが生じ, 表面電気二重層（表面双極子）そのものが 変化したことが原因であると指摘されている46。なお, IPES/2PPE/UPS の測定時において，分子に正孔や電子が生 じると, 電気的に中性な周辺分子による応答（分極効果） が生じる。分極効果の中身としては, 周辺分子による遮蔽 効果（誘起双極子による相互作用）や，中性分子がもとも と持つ電荷分布との間に働く静電相互作用（四重極子との 相互作用）が考えられる。吉田ら ${ }^{47,48}$ は 5 10 nm 程度の 膜厚を有する (本研究と比べると比較的厚い) 有機分子膜 について, UPS/IPES を用いた定量的な解析を占有・非占有 両準位について行っており，四重極子による静電相互作用 が分子配向によって大きく異なることを明らかにしてい る 47,48 。上記における先行研究の例は, いずれも分子量が 大きく, 比較的分極を起こしやすい分子群についての報告 であった。単純な構造を持つ分子であるナフタレンについ ても, 占有・非占有準位で同様に大きな電子状態変化が観 測されたことは興味深い。ただし, 本研究で扱った, 単分 子層程度の超薄膜で観測された結果を定量的に説明するに は，基板による鏡像効果も考慮に入れたモデルが必要とな り, 今後の課題として残されている。

微視的視点からの電子状態を検証するため, STMによる 局所分光を行い, 単一分子レベルで電子状態を計測した (Figure 5)。金属・半導体表面では, 電流 $(I)$-電圧 $(V)$ 測定によって電子状態を計測する手法が確立されている ${ }^{29}$ 。 これは STM 探針を高さ一定で固定し，電圧掃引時におけ るトンネル電流変化を検出する手法である。また, 電流の 微小変化分をロックイン検出するためにトンネル電流を大 きめに設定する必要もあり, 有機超薄膜を測定する場合に は電流によるダメージが起こることもある。加えて, 本研 究では2PPEと比較を行うため, フェルミ準位から離れた 比較的大きな值まで電圧掃引をする必要もある。このよう
な場合, 分子に大きなトンネル電流が流れやすくなり, 弱 い相互作用によって吸着・凝集した分子集合体自体が破壊 されてしまう問題もあった。本研究では, 有機超薄膜の計 測に最適化した手法（距離 $(z)$-電圧 $(V)$ 分光）を展開 し $^{31}$, マクロスケールの電子分光である $2 \mathrm{PPE}$ との直接比 較を可能とした。これはトンネル電流の值を一定に保ちつ つ, 電圧掃引に伴う探針の高さ変化を電子状態の変化分と して検出する手法である ${ }^{49,50}$ 。

Figure 5 に, ナフタレン薄膜における STM 局所分光の適 用例を示す。なお, 次節で詳述するように, 局所分光測定 は液体窒素温度（約 $80 \mathrm{~K}$ ) で行っており, 計測中の熱ドリ フトによる影響（数 丹程度）が避けられない。探針位置を 完全に固定した上でのデータ取得が難しいため, 同一構造 の膜上で複数取得したデータを平均したものを示している。 Figure 5 において, IPS ピークについては構造変化に伴って 高エネルギー側にピークシフトしていく様子が見られ， 2PPEの結果とよい一致が見られた。LUMOについては, $2 \sqrt{3}$ 構造上では $+3.4 \mathrm{~V}$ 付近にピークが見られたが, 多層膜 では同位置に観測されなくなっており，同様に2PPEにお ける結果と矛盾しない。また, Figure 6（b）に示した $2 \mathrm{PPE}$ では分子配向変化に伴って, 高エネルギー側にLUMO ピー クがシフトする様子が見られた。多層膜におけるLUMO ピーク強度は $2 \sqrt{3}$ 構造上よりもかなり小さくなるため, 局 所分光での検出は難しいものの, 両者の定性的な対応が取 れていることがわかった。

なお，2PPE および STM 局所分光で計測したエネルギー の絶対值については必ずしも一致しない。これは, STM 局 所分光については, 探針一試料間に電場をかけて分光計測 を行っており，主としてその影響を受けるためである ${ }^{31,51}$ いわゆるシュタルクシフトとして見込まれる両手法のエネ ルギー差は, 清浄表面の IPS 準位で $0.3-1.0 \mathrm{eV}$ 程度と実測 されており ${ }^{51}$, 表面の構成原子のみならず面指数によって も異なる值が報告されている。本稿で紹介した系も上記範 囲内の差が生じており，2PPEとの測定值の差は電場による 影響が大きい。定量的な解析は今後の課題となりうるが, IPES など他の測定法との比較も必要となってくる。

2PPE と IPES のエネルギー準位の比較においては, 電 子・正孔が分子に局在化しているのか（励起子状態に近い 状態にあるのか), 励起元の正孔が遮蔽・緩和されて消滅し ているとみなせるのか（IPES の場合と同様に，系に電子を 一つ加えた負イオンに近い状態を見ているのか)で，結果 の解釈の仕方が異なってくる 52 。例えば, 表面鏡像準位 (IPS) については，2PPE/IPES で計測されたエネルギー值 について，両者で良い一致を見せている（例：グラファイ ト清浄面ではともに $\left.E_{\mathrm{F}}+3.6 \mathrm{eV}{ }^{53}\right)$ 。2PPEにおいては, IPS 準位に励起される電子は基板（バルク）に由来しているた め, 励起元にできた正孔の緩和は非常に速い（Figure 7 (a))。このため, IPES 計測時と同様に，単純にIPS 準位に 

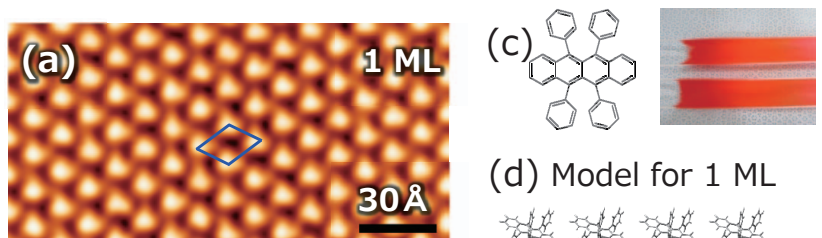

(d) Model for $1 \mathrm{ML}$
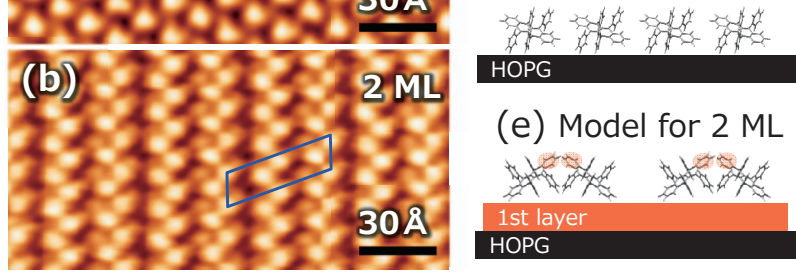

(e) Model for $2 \mathrm{ML}$

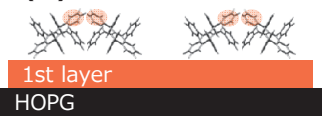

Figure 8. STM images for (a) $1 \mathrm{ML}$ (obtained at a sample bias $\left(V_{\mathrm{s}}\right)$ of $2.11 \mathrm{~V}$ and a tunneling current $\left(I_{\mathrm{t}}\right)$ of $\left.250 \mathrm{pA}\right)$ and (b) $2 \mathrm{ML}\left(V_{\mathrm{s}}=2.49\right.$ $\mathrm{V}, I_{\mathrm{t}}=30 \mathrm{pA}$ ) films of rubrene films, respectively. (c) Molecular structure of rubrene, with a photo of rubrene during the purification process. The structures in the films were determined from the images to be (d) predominantly lying in a monolayer film, and (e) standing in a tilted configuration in the second layer. Tetracene backbones are shown planar for simplicity, but in reality may be partially twisted.

電子が加わった状態を観測していることに相当する。

一方, 分子由来の非占有準位に関しては, 膜厚や構造に よって励起後の正孔の挙動が異なる。たとえば, 次節で採 り上げるルブレン超薄膜（Figure 8) において, 時間分解 2PEEを用いて励起電子の寿命を計測したところ, 単分子層 以下の膜厚においては, LUMO に励起された電子の寿命が 短いことが判明した ${ }^{27}$ 。これは LUMO 準位が基板の電子状 態と混成し, 励起後の正孔が基板に非局在化するためであ る。また, 概ね $3 \mathrm{ML}$ 以上の厚膜では分子一基板間相互作 用が弱くなるために，電荷が分子内に励起子として局在し， 再結合までの寿命が長くなる傾向にある。静的な電子状態 にとどまらず, 膜構造とともに電子 ·正孔の挙動を逐次把 握しつつ, 動的な電子状態の描像を得ることが要求される 段階に来ている。

\section{4. ルブレン超薄膜における非局在化した非占有準位 の分光イメージング}

本節ではルブレン超薄膜の非占有電子状態を計測した結 果を紹介し $27,54-57$, 電子状態の局在・非局在性に関して議 論したい。ルブレン (Figure 8 (c) ) は典型的な有機半導体 であり, 単結晶で良好な電荷移動度を示すことから ${ }^{58}$, そ の電子状態に興味がもたれている $59,60 。$ Figure 8 にグラファ イト上のルブレン薄膜の STM 像を示す $27,54,55$ 。ここでは輝 点一つが一分子に相当し，1 層膜と 2 層膜で異なった構造 を有することがわかった。特に 2 層目では 1 次元鎖状に分 子が整列した構造が表れ，ほぼ同様の格子定数をもつ 1 次 元鎖構造は $\mathrm{Au}(111)$ 基板上においても 2 層目以降で確認さ れている ${ }^{61}$ 。基板が異なるため, 各々における 1 層目の吸 着構造はまったく異なるものの, 2 層目以降では分子一基 板間相互作用を上回る形で分子間相互作用が働き始め, 両 基板上で似た構造が出現すると考えると興味深い。なお, グラファイト基板上に拈いては，3層目以降の膜厚では
LEED/STM で特定の構造が観測されず，アモルファス成長 が見られた ${ }^{27,54,55 。 ま た, ~} 10$ 分子層程度の厚膜における 2PPE/UPS スペクトルであっても，単結晶のものとはその 形状がかなり異なっており，前節で述べたナフタレンのよ うに，分子を堆積させると結晶が有する構造に近づく傾向 は観測されていない54。しかしながら，膜厚を増加させつ つ, 偏光依存 $2 \mathrm{PPE}$ 測定を行ったところ, $\mathrm{p} / \mathrm{s}$ 各偏光で計測 した2PPEの強度の比率が次第に大きくなることがわかっ た ${ }^{54}$ 。ここでは入射光の電場ベクトルが光入射面に平行 （垂直）である場合を $\mathrm{p}(\mathrm{s})$ 偏光と呼んでいる（Figure 9 (c)）。 また，本研究で使用した，4-5 eV 程度の光子エネルギーで 励起する場合においては，遷移双極子モーメントの向きは テトラセン長軸に対して平行であることがわかっている。 上記を考慮に入れると, 10 分子層程度の多層膜ではアモル ファス成長が続くものの（完全なランダム配向ではなく）, 分子長軸を表面垂直方向に傾ける傾向を保ちつつ，膜成長 していくことが判明した ${ }^{54}$ 。

また，単層膜以下の被覆率において $2 \mathrm{PPE}$ 測定を行うと， ルブレン分子由来の HOMO 準位と, Ln とラベル付けした 非占有準位間の共鳴励起が著しく増強された ${ }^{56,57 。 \text { Figure } 9}$ では, Ln 準位の軌道対称性を議論するため, 異なった波長 のポンプ光・プローブ光を用いて行った2 color-2PPEの結 果を示す。Figure 9（a）において，偏光依存 2PPE 測定を 行ったところ, Ln ピークはプローブ光が $\mathrm{p}$ 偏光のときにそ の強度が特に大きくなることがわかった。同様な傾向が IPS

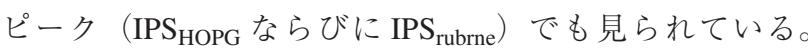
Figure 9 (c) には IPS 準位に対する光励起選択則の概略を 示した。自由電子的に振る舞う IPS の波動関数の対称性は 光入射面に対して偶対称であり, 同じく電場ベクトルが光 入射面に対して偶対称である $\mathrm{p}$ 偏光で検出する場合に遷移 双極子モーメントが nonzero 成分を持つ。Ln ピークの偏光 依存性はIPS と同じであり, 光入射面に対して高い対称性 を持つ軌道であることがわかる。一方で，ルブレン分子に 由来する他の非占有準位（F2, L1(LUMO+1) 等）に関して は, $\mathrm{p}$ 偏光検出時のスペクトルは $\mathrm{s}$ 偏光検出時のスペクト ルと相似関係にあり，節の多い一般的な非占有分子軌道の 性質を持つことがわかる。

広がった原子軌道を基底関数に組み込んだ量子化学計算 を行い 57 , 得られた Ln 軌道の電荷密度分布を Figure 10 (a) に示した。このような非占有準位は, 空間的に広がった, 節の少ないリュードベリ様分子軌道に分類される。超原子 分子軌道 (super atomic molecular orbital, SAMO) として Petek らが $\mathrm{C}_{60}$ 分子膜で最初に報告したものと起源が同様で あり ${ }^{62}$, 近年様々な多環芳香族分子を対象に実験・理論に よる研究が精力的に行われている ${ }^{63-66}$ 。気相における実験 でも，空間的に広がった分子軌道は観測されているが，そ の強度はかなり弱い64-66。一方, 固体表面に吸着した場合, 基板電子状態との混成により，分子内励起に加えて基板か 
(a) $0.7 \mathrm{ML}, h v_{\text {pump }} / h v_{\text {probe }}=4.43 \mathrm{eV} / 2.95 \mathrm{eV}$

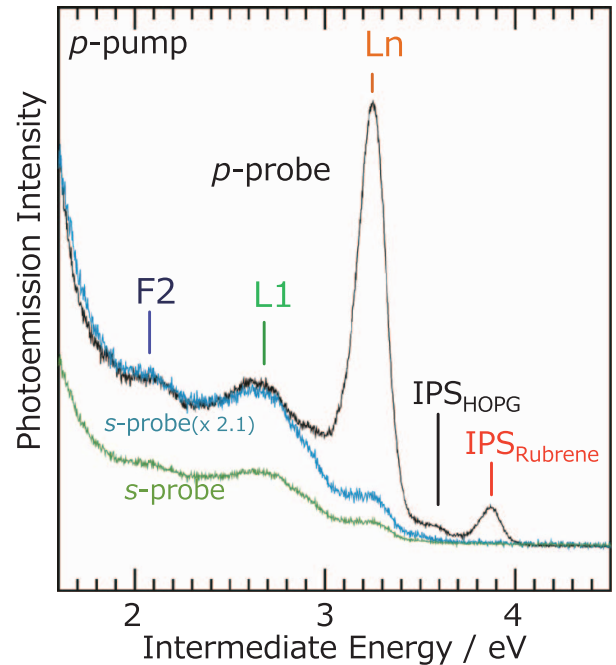

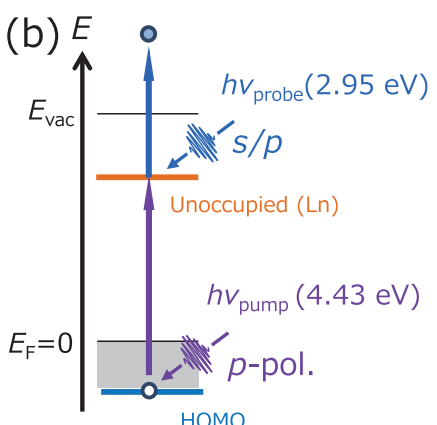

(C) IPS intensity $\propto|\langle f|\boldsymbol{\mu} \cdot \boldsymbol{E}| \mathrm{IPS}\rangle|^{2}$

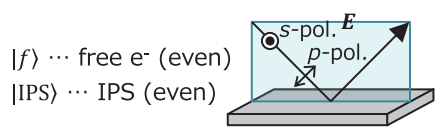

$p$-pol. (even) : $\langle$ even $|$ even $\mid$ even $\rangle \neq 0$ $s$-pol. (odd) : $\langle$ even $|$ odd $\mid$ even $\rangle=0$

Figure 9. (a) Polarization-dependent two-color $2 \mathrm{PPE}$ spectra for the rubrene film of $0.7 \mathrm{ML}$ coverage. The pump photon of $4.43 \mathrm{eV}$ was p-polarized. The black spectrum was measured with a p-polarized probe photon of $2.95 \mathrm{eV}$, and the green, with s-polarized. The green spectrum is multiplied by 2.1 and shown by the blue trace. The L1 and F2 peaks as well as the low energy feature of the blue trace overlap well with the black trace, whereas the Ln peak for the blue trace is weaker by a factor of about 10 than that of the black trace. (b) Schematic illustration of excitation diagram in (a). (c) Schematic illustration of the selection rule for IPS detected by 2PPE process, depending on the $(\mathrm{p} / \mathrm{s})$ polarization of the incident light plane. (a) is reproduced from ref. (57) with permission (Copyright 2013 American Chemical Society).

らの励起も可能となるため, その電子遷移確率が増大す る ${ }^{57}$ 。ルブレン吸着表面の場合, 非占有・表面鏡像準位 (IPS）との相互作用によって $2 \mathrm{PPE}$ 強度が増強されること がわかり，特に基板上の IPS が残る単分子層未満の膜厚で その増強が顕著である ${ }^{56,57}$ 。

Ln 準位の微視的描像を得るために, STM で構造を規定 したルブレン薄膜の 1 層膜 $/ 2$ 層膜上の各領域（Figure 10 (b) 中のX印付近）において, 局所分光を行った ${ }^{67}$ 。Figure 10 (c) は STM 局所分光の結果であり, 2PPE との比較か

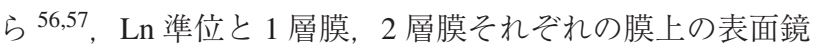
像準位（IPS）を同定した。なお, Figure 10 (c) の局所分 光において，2PPEの結果（Figure 9 (a)) と比べると, IPS の強度が相対的に強調されて大きくなっている。これはIPS の波動関数が真空側に大きく張り出しているためであり (Figure 7 (a), 文献 (39)-(41)), 真空側からプローブす る STM 探針で検出されやすいためである。

そのほか, Figure 9 (a) の 2PPE において, L1・F2 とラ ベル付けされたピークが分子由来の非占有準位として観測 されている。Lnピークとの位置関係を考えると, Figure 10 (c) の STM 局所分光では, L1・F2 ピークに対応する準位 が $+3 \mathrm{~V}$ 付近に観測されるものと予想される（緑の棒線近 傍のブロードなピーク)。しかしながら，実際に測定を行っ てみると, この領域では IPS ピーク以上に大きなピークと して現れることもあれば，観測にかからないこともあった。 同じ探針を用いて均一膜上を計測しているにもかかわらず, 毎回検出される $\mathrm{Ln} \cdot \mathrm{IPS}$ ピークと比べて L1 $\cdot \mathrm{F} 2$ ピークの
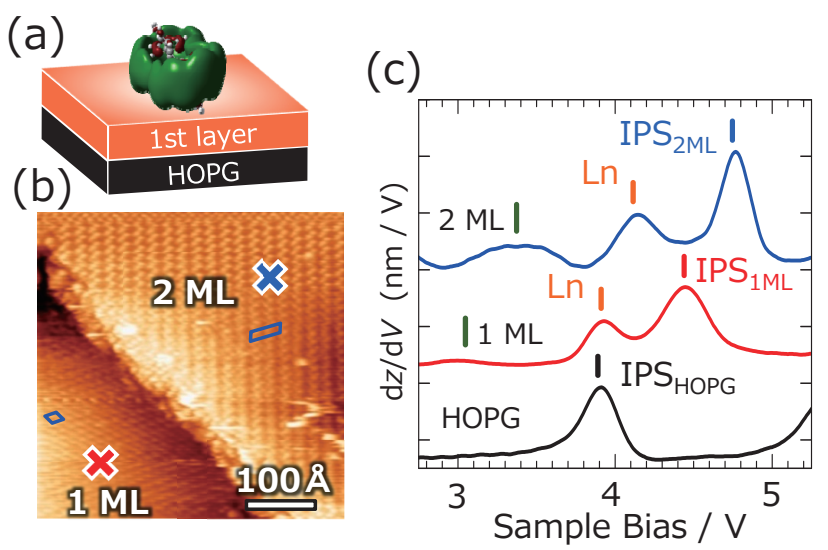

Figure 10. (a) Contours of the doughnut-like Ln orbital as obtained using the $6-31+\mathrm{G}^{*}$ diffuse basis set, shown in a tilted molecular orientation. (b) STM image of a rubrene film on HOPG. The first layer (1ML, lower left) and the second layer ( $2 \mathrm{ML}$, upper right) coexist and possess different superstructures. $V \mathrm{~s}=3.50 \mathrm{~V}, I_{\mathrm{t}}=10 \mathrm{pA}$. Rhombuses represent unit cells. (c) $\mathrm{d} z / \mathrm{d} V$ spectra of the $1 \mathrm{ML}$ (red) and $2 \mathrm{ML}$ (blue) regions, sampled near the points shown by red and blue crosses in (b), respectively. The spectrum taken on the clean HOPG substrate (black) is a reference and all spectra were taken with $I_{\mathrm{t}}=10 \mathrm{pA}$. Adapted from ref. (67) with permission from the PCCP Owner Societies.

検出効率が低いという結果が得られた。(なお, 局所分光前 後にはSTM 画像取得を行っており，膜の破壊が起こって ないことを確認している。）原因として, 本研究では STM 観察と局所分光を液体窒素温度 $(80 \mathrm{~K})$ で行っており, か つ一度のデータ取得に最大 1 分程度の時間を要するため, データ取得中に熱ドリフトによって試料と探針の相対位置 がずれた可能性が考えられる。また, Ln・IPS ピークと比 

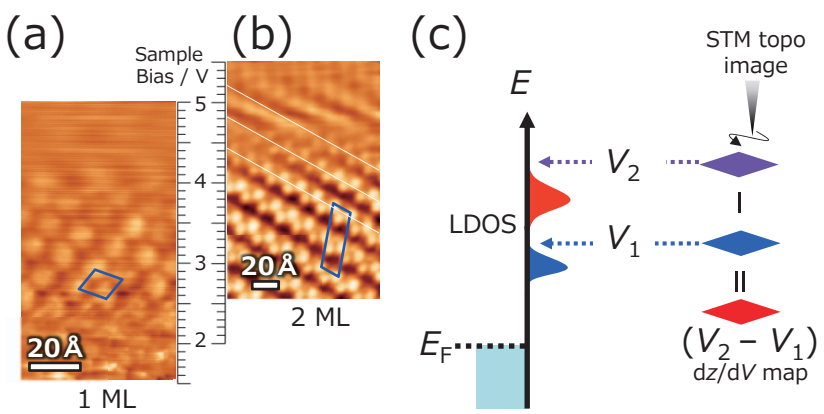

Figure 11. Constant current STM images of (a) $1 \mathrm{ML}$ and (b) $2 \mathrm{ML}$ rubrene films acquired while varying the sample bias. The sample bias is indicated at the side of each image. The tunneling current was set 2.6 pA for (a) and $13 \mathrm{pA}$ for (b). For clarity, the gradual increase in the tip height with increased sample bias is normalized in the images. The sample bias is indicated at the side of each image. (c) Basic concept of $\mathrm{d} z / \mathrm{d} V$ mapping. In the constant current mode, a topographic STM image integrates all of the local density of states (LDOS) located in the energy window between the Fermi level $\left(E_{\mathrm{F}}\right)$ and the sample bias set for imaging. By subtracting two constant-current topographic STM images taken at two different sample biases (e.g., $V_{1}$ and $V_{2}$ ), the LDOS located between the $V_{1}$ and $V_{2}$ energy levels can be evaluated. Reproduced from ref. (67) with permission from the PCCP Owner Societies.

ベて検出効率が落ちるという結果は, 波動関数の空間的な 広がりの差を反映しているとも考えられる。そこで，観測 された各ピークにおける電子状態の空間的広がりを議論す るため, 各非占有準位における電子状態マッピングを試み た。

Figure 11（a），11（b）はそれぞれ 1 層膜，2 層膜上にお いて, 一定電流モードで取得したSTM 像の電圧依存性を 示している。STMにおいては, 分子そのものが像として可 視化されるというよりは, フェルミ準位 $(0 \mathrm{~V})$ から設定電 圧值 $(V \mathrm{~s})$ までに存在する局所状態密度 (Local Density of States, LDOS）の積分值が可視化されていると解釈すべき である。例えば, Figure 11 (a) で示した 1 層膜における電 圧依存性では，2.5-3.5 V 付近で非占有準位の LDOS が多 く存在しているため, この試料電圧では良好な分子像が確 認できるが，それ以外の試料電圧では STM 像自体が見え にくくなることを示している。注目するエネルギーにおい て, Figure $10(\mathrm{c})$ の縦軸に相当する $\mathrm{d} z / \mathrm{d} V$ 強度をマッピン グするためには, 同一場所において異なる電圧で取得した STM 像同士の減算を行い, STM の差分像を作ることが有 効になる（Figure 11 (c))。

Figure 12 (a), 12 (b) に, ルブレン 2 層膜における非占 有準位 $(+3.2 \mathrm{~V})$, Ln 準位 $(+4.2 \mathrm{~V})$ 付近における STM 像 をそれぞれ示した。両者は同一ドメイン内の異なった領域 でSTM 像を取得しているが, ともに Figure 8（b）で示し た 1 次元鎖構造が表れており, STM 像の見た目としては大 きな差異は見られない。そこで, 両画像を取得したエネル ギーにおいて電子状態マッピングを試みた。Figure 12 (d) のマッピング像（+3.2 V で取得）は分子が存在する位置で その強度が大きくなっており, 対応する非占有準位が分子 直上に局在していることを示す。一方, Figure 12 (e) の

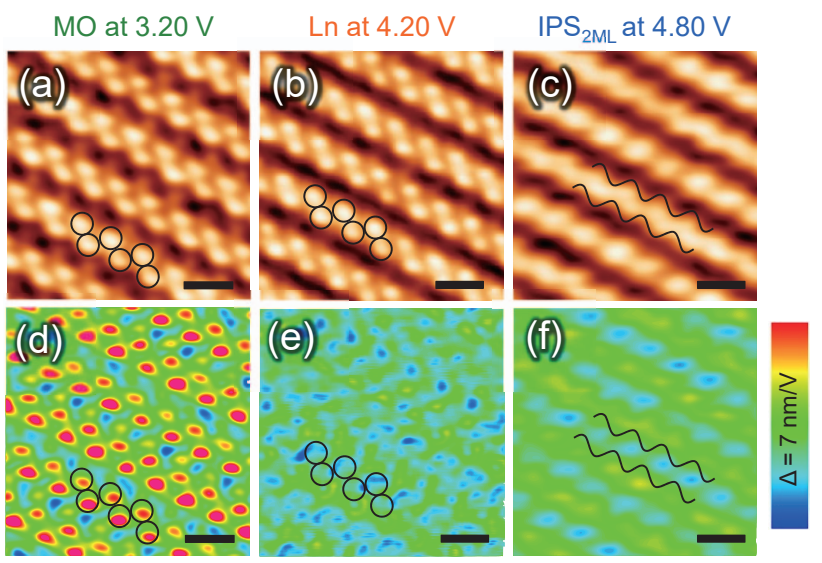

Figure 12. STM images of $2 \mathrm{ML}$ rubrene film. (a) $V_{\mathrm{s}}=3.20 \mathrm{~V}, I_{\mathrm{t}}=14$ pA. (b) $V \mathrm{~s}=4.20 \mathrm{~V}, I_{\mathrm{t}}=13 \mathrm{pA}$. (c) $V \mathrm{~s}=4.80 \mathrm{~V}, I_{\mathrm{t}}=12 \mathrm{pA}$. (d) $\mathrm{d} z / \mathrm{d} V$ image generated from the images at $V_{\mathrm{s}}=3.10 \mathrm{~V}$ and $V_{\mathrm{s}}=3.20 \mathrm{~V}$, which correspond to the LDOS map of one of the localized unoccupied molecular states. (e) $\mathrm{d} z / \mathrm{d} V$ image generated from the images at $V \mathrm{~s}=4.20$ and $V \mathrm{~s}=4.10 \mathrm{~V}$, corresponding to the LDOS map of the delocalized $\mathrm{Ln}$ level. (f) $\mathrm{d} z / \mathrm{d} V$ image generated from the images at $V \mathrm{~s}=4.80 \mathrm{~V}$ and $V \mathrm{~s}=4.70 \mathrm{~V}$, corresponding to the LDOS map of the IPS ${ }_{2 \mathrm{ML}}$ level. The same color scale is used for (d), (e), and (f). The images in (a), (b) and (c) were obtained from different places in the same domain. All scale bars are $20 \AA$. Circles and wavy lines in the images are included simply as visual guides. Reproduced from ref. (67) with permission from the PCCP Owner Societies.

Ln 準位付近で取得したマッピング像では，12（d）の非占 有準位に比べると像コントラストは極端に弱い。これは Ln 準位における電子状態が表面全体に非局在化した傾向を示 しており，2PPE（Figure 9（a)）で得られた，空間的に広 がった分子軌道の描像を分子レベルでとらえた結果である。 同様の傾向は，IPS 準位におけるマッピング像（Figure 12 (f)）でも見られている。Figure 7（b）で示したように, IPS 準位にある電子は表面平行方向には 2 次元自由電子的 にふるまうため, Figure 12 (f) において非局在化した準位 が観測された事実は妥当であると考えられる。また，ここ で述べた非占有準位の局在性・非局在性は Figure 10 (c) の 局所分光を行った際に問題となった，各ピークの検出効率 の差に影響していると考えられる。

分子軌道の局在性・非局在性は有機薄膜中の電荷輸送を 考える上で重要な要素でもある。本研究では, STM 局所分 光と $2 \mathrm{PPE}$ を併用することにより, 非占有準位の微視的描 像をナノスケールで捉えることが可能であることを示した。 一連の非占有準位計測や局所分光イメージングを通し, 分 子／基板界面における，特徵的な非占有電子状態の描像を 一分子レベルで評価することができる段階に到達できつつ あると考えている。

\section{5. まとめと今後の展望}

本稿では，単分子層程度の有機分子・有機半導体による 超薄膜を対象とし, 非占有電子状態と構造の相関を実験的 に明らかにした例を紹介した。2 光子光電子分光を用いた 表面分光は 1980 年代から開始されたが ${ }^{19}$, 議論に耐えうる 
データが出るようになったのは 90 年代以降 $20-22$ であり, 理論的解釈も充実しつつある段階に来ている ${ }^{23}$ 。当初の計

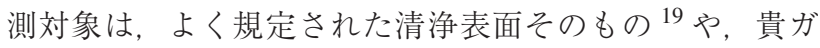
ス・ 2 原子分子等に代表される単純な構造を持つ分子の吸 着系が多かった。

超薄膜試料作製における試行錯誤が積み重ねられ ${ }^{13-15}$, 計測技術に関わるノウハウが不断の努力によって確立され た結果，比較的サイズの大きな分子からなる超薄膜を取り 扱えるようになり，今後においても多様な分子群にその対 象を拡充させていくことができると感じている。本稿で紹 介したように, 超薄膜の構造情報と併せることにより, 単 分子層レベルで電子状態を議論できるようになった意義は 大きく, 占有準位も含めた界面電子状態を統括的に理解す るための一歩となることが期待される。

現在, 筆者らは励起状態における電荷の挙動や電子状態 の理解とどまらず, 脱励起に伴う分子からの発光にも興味 の対象を広げて研究を行っている。具体例として, ペリレ ン単分子層中に形成された励起 2 量体からの発光と, 界面 における膜構造との相関に関しては，特に興味を持ってい る ${ }^{68}$ 。なお, 2 分子層目以降の超薄膜からの発光について はペリレン誘導体における報告例があるものの ${ }^{69,70}$, 失活 が速いとされる単分子層からの発光は, 目視で確認できる レベルでの報告例が見当たらない。今後は時間分解 $2 \mathrm{PPE}$ を活用し，占有・非占有各準位における正孔・電子の動的 挙動を解析することで, 分子吸着表面における発光現象の 描像を捉えることを試みる予定である。

本稿で紹介した研究は多くの方々のご指導とご協力に支えられ て行うことができました。宗像利明先生（大阪大学名誉教授）に は, 筆者にとって未踏領域であった 2 光子光電子分光の世界に誘っ ていただくと同時に，様々な面で多大なご支援を頂きました。ま た，共同で研究を行っていただきました歴代の研究室メンバーに 深く感謝いたします。LEEDを用いた精密構造解析に関しては, Torsten Fritz 教授（ドイツ・イエナ大学物理学科）ならびに同研究 室メンバーとの共同研究を通じて行ったものであり, ドイツ学術 振興会（DAAD-PAJAKO Projekt）による援助と併せて，ここにお 礼申し上げます。本研究は科学研究費補助金（若手研究 (A) / (B), 基盤研究 (C), 挑戦的萌芽研究) ならびに住友財団, 村田 学術振興財団, コニカミノルタ科学技術振興財団からの研究費の 支援を受けて行われました。

\section{参考文献}

(1) Brütting, W.; Adachi, C. Eds. Physics of organic semiconductors, 2nd ed., Wiley-VCH Verlag GmbH: Weinheim, Germany, 2012.

(2) Cahen, D.; Kahn, A.; Umbach, E. Mater. Today. 2005, 8, 32-41.

(3) Ishii, H.; Sugiyama, K.; Ito, E.; Seki, K. Adv. Mater. 1999, 11, 605-625.

(4) Ishii, H.; Kudo, K.; Nakayama, T.; Ueno, N. Eds. Electronic Processes in Organic Electronics, Springer Series in Materials Science 209; Springer, 2015.

(5) Yamamoto, R.; Yamamoto, I.; Mikamori, M.; Yamada, T.;
Miyakubo, K.; Munakata, T. Surf. Sci. 2011, 605, 982-986.

(6) Kawakita, N.; Yamada, T.; Meissner, M.; Forker, R.; Fritz, T.; Munakata, T. Phys. Rev. B 2017, 95, 045419.

(7) Yamamoto, R.; Yamada, T.; Taguchi, M.; Miyakubo, K.; Kato, H.; Munakata, T. Phys. Chem. Chem. Phys. 2012, 14, 9601-9605.

(8) Yamamoto, I.; Mikamori, M.; Yamamoto, R.; Yamada, T.; Miyakubo, K.; Ueno, N.; Munakata, T. Phys. Rev. B 2008, 77, 115404.

(9) Shibuta, M.; Yamamoto, K.; Miyakubo, K.; Yamada, T.; Munakata, T. Phys. Rev. B 2010, 81, 115426.

（10）小間篤 ほか 編, 表面物性工学ハンドブック 第 2 版 ; 丸善 出版 : 東京, 2007.

（11） 日本表面科学会 編, 現代表面科学シリーズ 全 6 巻; 共立出 版：東京, 2011-2013.

(12) Hüfner, S. Photoelectron Spectroscopy 3rd ed., Springer, 2013.

(13）山根宏之, Molecular Science（分子科学会誌） 2015, 9, A0078.

(14) Kera, S.; Yamane, H.; Ueno, N. Prog. Surf. Sci. 2009, 84, 135154.

（15）解良聡, 上野信雄, 真空 2013, 56(1), 18-23.

（16）平本昌宏, Molecular Science（分子科学会誌）2012, 6, A0052.

(17) Yoshida, H. Chem. Phys. Lett. 2012, 539-540, 180-185.

（18）吉田弘幸, 応用物理 2015, 84, 245-249.

(19) Giesen, K.; Hage, F.; Himpsel, F. J.; Riess, H. J.; Steinmann, W. Phys. Rev. Lett. 1985, 55, 300.

(20) 宗像利明, 表面科学 1994, 15, 501-506.

(21) Velic, D.; Hotzel, A.; Wolf, M.; Ertl, G. J. Chem. Phys. 1998, 109, 9155 .

(22) 小川晋, Hrvoje Petek, 表面科学 1998, 19, 72-77.

(23) Bovensiepen, U.; Petek, H.; Wolf, M. (Eds.), Dynamics at solid state surfaces and interfaces, Vol. 2, Wiley-VCH Verlag GmbH, Berlin, 2012.

（24）宗像利明, 杉山武晴, 表面科学 2005, 26, 729-733.

(25) Yamada, T.; Yamamoto, R.; Munakata, T. J. Electron Spectrosc. Rel. Phenom. 2015, 204, 145-148.

(26) Yamamoto, R.; Yamamoto, I.; Mikamori, M.; Yamada, T.; Miyakubo, K.; Munakata, T. Surf. Sci. 2011, 605, 982-986.

(27) Ueba, T.; Yamada, T.; Munakata, T. J. Chem. Phys. 2016, 145, 214703.

(28) Shibuta, M.; Miyakubo, K.; Yamada, T.; Munakata, T. J. Phys. Chem. C 2011, 115, 19269-19273.

(29）重川秀実, 吉村雅満, 河津璋 編, 走査プローブ顕微鏡一正 しい実験とデー夕解析のために必要なこと一（実験物理科 学シリーズ 6)；共立出版：東京, 2009.

(30) Yamada, T.; Takano, Y.; Isobe, M.; Miyakubo, K.; Munakata, T. Chem. Phys. Lett. 2012, 546, 136-140.

(31) Yamada, T.; Isobe, M.; Shibuta, M.; Kato, H. S.; Munakata, T. J. Phys. Chem. C 2014, 118, 1035-1041.

(32) Sojka, F.; Meissner, M.; Yamada, T.; Munakata, T.; Forker, R.; Fritz, T. J. Phys. Chem. C 2016, 120, 22972-22978.

(33) Sojka, F.; Meissner, M.; Zwick, C.; Forker, R.; Fritz, T. Rev. Sci. Instrum. 2013, 84, 015111.

(34) Capelli, S. C.; Albinati, A.; Mason, S. A.; Willis, B. T. M. J. Phys. Chem. A 2006, 110, 11695-11703.

(35) Forker, R.; Meissner, M.; Fritz, T. Soft Matter 2017, 13, 1748 1758. 
(36) Wella, S. A.; Sawada, H.; Kawaguchi, N.; Muttaqien, F.; Inagaki, K.; Hamada, I.; Morikawa, Y.; Hamamoto, Y. Phys. Rev. Materials 2017, 1, 061001.

(37) Baba, M.; Kowaka, Y.; Nagashima, U.; Ishimoto, T.; Goto, H.; Nakayama, N. J. Chem. Phys. 2011, 135, 054305.

（38）当初の報文 ${ }^{30,31}$ では Figure 5（c）のSTM 像中の○印で囲 んだ輝点 1 つがナフタレン分子中のベンゼン環 1 つに相当 すると考え, 多層膜でも分子面が基板に対して平行な配置 を取るモデルを想定していた。

(39) Güdde, J.; Höfer, U. Prog. Surf. Sci. 2005, 80, 49-91.

(40) Chulkov, E. V.; Silkin, V. M.; Echenique, P. M. Surf. Sci. 1999, 437, 330-352.

(41) Echenique, P. M.; Berndt, R.; Chulkov, E. V.; Fauster, Th.; Goldmann, A.; Höfer, U. Surf. Sci. Rep. 2004, 52, 219-317.

(42) Cole, M. W. Phys. Rev. B 1971, 3, 4418.

(43) Neaton, J. B.; Hybertsen, M. S.; Louie, S. G. Phys. Rev. Lett. 2006, 97, 216405.

(44) Duhm, S.; Heimel, G.; Salzmann, I.; Glowatzki, H.; Johnson, R. L.; Vollmer, A.; Rabe, J. P.; Koch, N. Nat. Mater. 2008, 7, $326-332$.

(45) Salzmann, I.; Duhm, S.; Heimel, G.; Oehzelt, M.; Kniprath, R.; Johnson, R. L.; Rabe, J. P.; Koch, N. J. Am. Chem. Soc. 2008, 130, 12870-12871.

(46) Heimel, G.; Salzmann, I.; Duhm, S.; Koch, N. Chem. Mater. 2011, 23, 359-377.

(47) Yoshida, H.; Yamada, K.; Tsutsumi, J.; Sato, N. Phys. Rev. B 2015, 92, 075145.

(48) Yamada, K.; Yanagisawa, S.; Koganezawa, T.; Mase, K.; Sato, N.; Yoshida, H. Phys. Rev. B 2018, 97, 245206.

(49) Binnig, G.; Frank, K. H.; Fuchs, H.; Garcia, N.; Reihl, B.; Rohrer, H.; Salvan, F.; Williams, A. R. Phys. Rev. Lett. 1985, 55, 991.

(50) Becker, R. S.; Golovchenko, J. A.; Swartzentruber, B. S. Phys. Rev. Lett. 1985, 55, 987.

(51) Dougherty, D. B.; Maksymovych, P.; Lee, J.; Feng, M.; Petek, H.; Yates, Jr., J. T. Phys. Rev. B 2007, 76, 125428.

(52）宗像利明，分光研究 2014, 63, 144-154.

(53) Maeda, F.; Takahashi, T.; Ohsawa, H.; Suzuki, S.; Suematsu, S. Phys. Rev. B 1988, 37, 4482.

(54) Ueba, T.; Park, J.; Terawaki, R.; Watanabe, Y.; Yamada, T.; Munakata, T. Surf. Sci. 2016, 649, 7-13.
(55) Udhardt, C.; Forker, R.; Gruenewald, M.; Watanabe, Y.; Yamada, T.; Ueba, T.; Munakata, T.; Fritz, T. Thin Solid Films 2016, 598, $271-275$.

(56) Park, J.; Ueba, T.; Terawaki, R.; Yamada, T.; Kato, H. S.; Munakata, T. J. Phys. Chem. C 2012, 116, 5821-5826.

(57) Ueba, T.; Terawaki, R.; Morikawa, T.; Kitagawa, Y.; Okumura, M.; Yamada, T.; Kato, H. S.; Munakata, T. J. Phys. Chem. C 2013, 117, 20098-20103.

(58) Takeya, J.; Yamagishi, M.; Tominari, Y.; Hirahara, R.; Nakazawa, Y.; Nishikawa, T.; Kawase, T.; Shimoda, T.; Ogawa, S. Appl. Phys. Lett. 2007, 90, 102120.

(59) Machida, S.; Nakayama, Y.; Duhm, S.; Xin, Q.; Funakoshi, A.; Ogawa, N.; Kera, S.; Ueno, N.; Ishii, H. Phys Rev Lett. 2010, 104, 156401.

(60) Bussolotti, F.; Yang, J.; Yamaguchi, T.; Yonazawa, K.; Sato, K.; Matsunami, M.; Tanaka, K.; Nakayama, Y.; Ishii, H.; Ueno, S.; Kera, S. Nat. Commun. 2017, 8, 173.

(61) Pivetta, M.; Blüm, M.-C.; Patthey, F.; Schneider, W.-D. J. Phys. Chem. B 2009, 113, 4578-4581.

(62) Feng, M.; Zhao, J.; Petek, H. Science 2008, 320, 359-362.

(63) Dougherty, D. B.; Feng, M.; Petek, H.; Yates, Jr., J. T.; Zhao, J. Phys. Rev. Lett. 2012, 109, 266802.

(64) Zoppi, L.; Martin-Samos, L.; Baldridge, K. K. Phys. Chem. Chem. Phys. 2015, 17, 6114-6121.

(65) Johansson, J. O.; Campbell, E. E. B. Chem. Soc. Rev. 2013, 42, $5661-5671$.

(66) Bohl, E.; Mignolet, B.; Johansson, J. O.; Remacle, F.; Campbell, E. E. B. Phys. Chem. Chem. Phys. 2017, 19, 24090-24099.

(67) Yamada, T.; Kinoshita, M.; Araragi, K.; Watanabe, Y.; Ueba, T.; Kato, H. S.; Munakata, T.; Phys. Chem. Chem. Phys. 2018, 20, $17415-17422$.

（68）山田剛司, 伊藤菜摘, 河北徳明, 加藤浩之, 宗像利明, 第 11 回分子科学討論会, 仙台, 2017 年 9 月 15-18 日, 2B14.

(69) Gebauer, W.; Langner, A.; Schneider, M.; Sokolowski, M.; Umbach, E. Phys. Rev. B 2004, 69, 155431.

(70) Ino, D.; Yamada, T.; Kawai, M. J. Chem. Phys. 2008, 129, 014701 .

（受理日 2018 年 7 月 14 日)

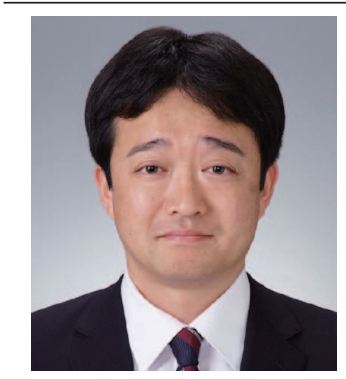

山田 剛司（やまだ たかし）

所属 : 大阪大学大学院理学研究科化学専攻

専門分野：固体表面に招ける物理化学 (表面化学), 表面物性計測

連絡先：干 560-0043 大阪府豊中市待兼山町 1-1

電子メール : tyamada@chem.sci.osaka-u.ac.jp

URL : http://www.chem.sci.osaka-u.ac.jp/lab/munakata/ 